DOI https://doi.org/10.32782/2305-9389/2020.23.14

УДК 355.433

Поплавський Олег,

кандидат історичних наук, дочент, професор кафедри військової підготовки Університету митної справи та фінансів

\title{
ВІЙСЬКОВИЙ СКЛАДНИК ЗАГАЛЬНОГО УСПІХУ АЗЕРБАЙДЖАНУ У «ДРУГІЙ КАРАБАСЬКІЙ ВІЙНІ»
}

У статті проведено аналіз процесу модернізаиії азербайджанської армії напередодні «другої карабаської війни». 3 відкритих джерел засобів масової інформації з'ясована загальна хронологія розгортання бойових дій, розглянута практика бойового застосування новітніх систем озброєння та військової техніки, визначені особливості збройного протистояння в умовах гірської місиевості, а також сумісного застосування безпілотної авіації, ракетних військ і артилерії. За допомогою аналізу планомірного і поступового проиесу переозброєння азербайджанської армї протягом останнього десятиріччя доведено, щзо в сучасних умовах лише модернізована, технологічно спроможна армія в змозі успішно протистояти агресії, захищати недоторканість держави та ї̈ національні інтереси. На підставі порівняння показників військової могутності ворогуючих сторін продемонстрована значна перевага бойового потениіалу Азербайджану над Вірменією. Досліджено розвиток форм та методів ведення інформаційно-психологічного протиборства з боку Азербайджану, здійснення енергійного деструктивного впливу на моральний стан противника. Надана очінка оперативної та професійної роботи азербайджанських засобів масової інформації на всіх етапах бойових дій. Встановлено, щзо в бойовому застосуванні армійських підрозділів особливе місие посіли сили спеціальних операцій Азербайджану, котрі під час війни фактично перетворилися на якісний компонент як Збройних сил, так і військової організації держави. Встановлено, щчо одним із головних чинників перемоги Азербайджану у військовому конфлікті з Вірменією на території Нагірного Карабаху було не тільки технічне оснащення армії, а й нова система організації та прийняття рішень у війську, абсолютна інша система розвідки і мережевої центричної війни та система горизонтальних прийнять рішень.

Ключові слова: Карабах, війна, бойові дії, безпілотна авіачія, реактивна і ствольна артилерія, інформаційнопсихологічний вплив, засоби масової інформації.

\section{Poplavskyi Oleh. Military component of the overall success of Azerbaijan in the "second Karabakh war"}

The article analyzes the process of modernization of the Azerbaijani army on the eve of the «second Karabakh war». The general chronology of the deployment of hostilities was clarified from open media, the practice of combat use of the latest weapons and military equipment was considered, the peculiarities of armed confrontation in mountainous areas, as well as the joint use of unmanned aerial vehicles, missile forces and artillery were identified. Through the analysis of the planned and gradual process of rearmament of the Azerbaijani army over the last decade, it has been proved that in modern conditions only a modernized, technologically capable army can successfully resist aggression, protect the inviolability of the state and its national interests. Based on the comparison of the indicators of military power of the warring parties, a significant advantage of Azerbaijan's combat potential over Armenia was demonstrated. The development of forms and methods of information and psychological confrontation on the part of Azerbaijan, the implementation of vigorous destructive influence on the morale of the enemy has been studied. An assessment of the operational and professional work of the Azerbaijani mass media at all stages of hostilities is given. It has been established that a special place in the combat use of army units was occupied by the special operations forces of Azerbaijan, which in the course of the war actually became a qualitative component of both the Armed Forces and the military organization of the state. It was established that one of the main factors in Azerbaijan's victory in the military conflict with Armenia in Nagorno-Karabakh was not only the technical equipment of the army, but also a new system of organization and decision-making in the army, a completely different system of intelligence and network centric warfare.

Key words: Karabakh, war, hostilities, unmanned aerial vehicles, jet and artillery, information and psychological influence, mass media.

Вступ. Аналіз останніх військових конфліктів і локальних війн у Грузії, Україні, Сирії, Лівії та інших регіонах планети наочно демонструє, що практично в кожному з них має місце новий формат ведення бойових дій, руйнуються класичні уявлення про форми та методи збройної боротьби на полі бою, вносяться суттєві корективи у стратегію і тактику досягнення переможних для кожної сторони результатів. Одним із них став так званий «карабаський конфлікт» між Вірменією та Азербайджаном за контроль над територією Нагірного Карабаху, який триває через територіальну суперечку про його статус вже понад 30 років. За радянських часів ця територія входила до складу Азербайджанської РСР у статусі автономної області, але була населена переважно вірменами. Після розпаду СРСР суперечки 
щодо її приналежності призвели до продовження повномасштабної війни, яка закінчилася в 1994 p. перемир'ям. Нагірний Карабах за міжнародним правом належить Азербайджану, але фактично його територію, а також територію так званого «поясу безпеки» із семи прилеглих азербайджанських районів (Агдамського, Губадлінського, Джебраїльського, Зангіланського, Кельбаджарського, Лачинського та Фізулінського) більш двадцяти років контролювали вірменські сили із самопроголошеної НагірноКарабаської республіки. Весь цей час офіційний Баку вважав цю територію (а це 20\% території Азербайджану в рамках його міжнародно визнаних кордонів) окупованою. Події вересня-листопада 2020 р., які в науковому середовищі отримали назву «другої карабаської війни», для багатьох військових експертів фактично стали новою сторінкою розвитку сучасних поглядів на роль і місце системи управління бойовими діями, організації та прийняття рішень у війську, стан модернізації озброєння та військової техніки, інформаційне забезпечення проведення бойових операцій та ін.

Актуальність цієї теми для нас є безумовною, оскільки саме нині наша країна опинилася в епіцентрі кровопролитного російсько-українського конфлікту, в процесі якого вже тривалий час Україна залишається об'єктом агресії з боку Російської Федерації. Отже, саме нині питання аналізу новітнього формату ведення бойових дій у процесі локальних війн і збройних конфліктів, у тому числі й карабаського, стає дуже актуальним і потребує негайної серйозної уваги фахівців і аналітиків. Україна веде боротьбу на Донбасі проти проросійських «проксі», які за стилем ведення бойових дій та станом озброєння сильно нагадують армію карабаських вірмен, тим більше, що за спиною і тих, і тих стоїть Російська федерація. Вивчення прикладу Азербайджану в цьому конфлікті для нас $є$ актуальним тому, що саме Азербайджан намагається звільнити окуповані Вірменією власні території, а також тому, що, на нашу думку, саме азербайджанська армія в процесі цієї війни продемонструвала високу ефективність як на полі бою, так і в інших компонентах військової могутності.

Ця проблема завжди була в центрі уваги закордонних і вітчизняних політологів, істориків, спеціалістів із міжнародного права. Серед закордонних науковців до розгляду та аналізу цієї проблематики звертались Г. Здравомислов, С. Золян, С. Корнелл, Е. Марибашир, П. Рустамова та ін. Їхні роботи були присвячені аналізу причин та генезису збройного протистояння між Азербайджаном і Вірменією, пошуку можливих перспектив вирішення цього конфлікту та ролі в цьому процесі РФ та ін. [1].

Не залишали поза увагою цю проблему і вітчизняні дослідники. Серед них варто згадати О. Алексійченко, І. Зельмановича, Г. Коржа, Ю. Райхеля, А. Рябеку, Ю. Чирву та ін. Вони також звертались до історичних витоків, політичного підгрунтя, передумов виникнення нагірно-карабаського конфлікту, ролі Кремля у підвищенні його температури, пошуків політичних механізмів розв'язання цієї проблеми [2]. Але аналіз бойових дій між ворогуючими сторонами, використання новітніх систем озброєння, тактичних прийомів, які застосовувалися в процесі боїв обома сторонами особливо на фоні втягування в конфлікт тією чи іншою мірою світових і регіональних гравців зі своїми інтересами, продовжують бути в центрі уваги лише журналістів або блогерів різного рівня.

Метою статті $\epsilon$ аналіз причин та передумов успішного для азербайджанської сторони результату «другої карабаської війни».

Методи дослідження. Для розв'язання поставлених наукових завдань використано такі методи дослідження: історико-теоретичний метод, який використовувався для вивчення відповідної літератури про передумови і причини конфлікту навколо Нагірного Карабаху, комплексно-аналітичний метод, який допомагав осмислити базові поняття і генезис вірмено-азербайджанського конфлікту, порівняльний метод, який давав змогу зіставити зміни у стані військової могутності ворогуючих сторін, а також методи спостереження, вивчення документів та узагальнення.

Результати. Першим дзвіночком, який продемонстрував перевагу Азербайджану на Південному Кавказі в наступальних озброєннях, для військових аналітиків став спалах так званої «чотириденної війни» - поновлення бойових дій в районі Нагірного Карабаху у квітні 2016 р. Внаслідок бойових зіткнень вірмени втратили контроль над частиною площі «поясу безпеки», за різними даними, від 500 до 800 га. Після цього в регіоні було встановлено порівняне затишшя, яке діяло практично до літа $2020 \mathrm{p}$.

У середині липня 2020 р. на міжнародно визнаній ділянці азербайджано-вірменського кордону між Тавуською областю Вірменії та Товузьким районом Азербайджану відбулися збройні сутички між ворогуючими сторонами, які призвели до людських жертв. Баку і Єреван звинуватили одне одного в порушенні режиму припинення вогню і застосуванні артилерії. Вже наступного дня азербайджанська влада зробила кілька заяв про знищення вогневих позицій, бойової техніки, втрати особового складу з боку вірменської армії. Прес-служба Міністерства оборони Азербайджану повідомила про загибель начальника штабу 3-го армійського корпусу генерал-майора П. Гашимова та начальника артилерії цього 
корпусу полковника I. Мірзоєва, а також кількох військовослужбовців. 15 липня в Баку тисячі людей вийшли на акцію на підтримку армії.

Значного інформаційного супроводу в цей час також набули показові спільні азербайджано-турецькі навчання, які пройшли 29 липня по 10 серпня 2020 р. на території Азербайджану в районах Баку, Нахичевані, Гянджі, Кюрдамиру та Євлаха. У навчаннях були задіяні особовий склад, бронетехніка, артилерійські установки і міномети, а також авіація та засоби ППО армій двох країн. Коментуючи проведення цих навчань, прес-секретар президента Туреччини I. Калин заявив, що його країна сповнена рішучості до кінця відстоювати інтереси Азербайджану, незалежно від джерел загрози - будь то Вірменія, Росія або будь-яка інша країна. Він наголосив: «Ми виступаємо на боці Азербайджану. Сдність, цілісність і безпека Азербайджану рівносильні єдності та безпеці Туреччини» [3].

А вже 27 вересня 2020 р. уздовж усієї лінії зіткнення починаються бойові дії із застосуванням важкої зброї. Загалом бої розгорнулися за двома напрямами - на півночі і півдні Карабаху. На півночі діяв 1-й корпус під командуванням генерал-майора Х. Гасанова, на півдні - дві військових групи під командуванням генерал-лейтенанта X. Мірзаєва і генерал-майора М. Бархударова. Протягом кількох днів Азербайджан не міг змінити ситуацію на свою користь і бої відбувалися в районах уздовж лінії зіткнення, але до 9 жовтня на півдні азербайджанські сили взяли м. Джебраїл - адміністративний центр одного з семи районів Азербайджану поза територією колишньої радянської Нагірно-Карабаської автономної області, які вірменські сили повністю або частково захопили у війні 1992-1994 рр. Ще через пару днів вони встановила контроль над м. Гадрутом - це перший райцентр на території власне Нагірного Карабаху, а не окупованих районів Азербайджану. Саме з падіння Гадрута ситуація змінилася - азербайджанські війська стали просуватися більш інтенсивно, а вірмени - відступати. Азербайджанські сили наступали в основному на півдні, уздовж вірмено-іранського кордону. Після Джебраїла і Гадрута Азербайджан встановив контроль над Фізулі, Зангеланом, Кубатли. Цілями цього наступу було місто Лачин, через яке проходить шосе, що зв’язує Шушу і Степанакерт із Вірменією, а також саме місто Шуша.

Військова операція азербайджанської армії в Нагірному Карабаху, яка тривала 44 дні, закінчилася успіхом для наступаючої сторони. До 9 листопада азербайджанські війська змогли взяти під контроль стратегічно важливе місто Шуша і підійти до столиці невизнаної Нагірно-Карабаської республіки Степанакерту (в азербайджанському варіанті - Ханкенді). Ключова для забезпечення НКР Лачинська дорога також була перерізана азербайджанцями, після чого нормальне постачання вірменських сил стало практично неможливим.

9 листопада 2020 р. Азербайджан, Вірменія та Росія підписали угоду, яка передбачала припинення бойових дій у Нагорному Карабасі. Півторамісячна війна скінчилася безумовною перемогою Азербайджану. Саме так заявив президент Азербайджану I. Алієв, на зустрічі з пораненими військовими у шпиталі м. Баку 11 листопада 2020 р. назвавши цю війну «вітчизняною» [4]. У військовому плані збройні формування Вірменії та їх «проксі» з так званої «республіки Арцах» зазнали вражаючої поразки. Азербайджанська армія звільнила більше двохсот населених пунктів. Основні комунікації між Нагорним Карабахом і Вірменією були заблоковані. Повністю взяті під контроль окремі стратегічні висоти і кілька населених пунктів на півночі регіону. Гарантовано, хоч і під наглядом російських «миротворців», користування Азербайджану стратегічним Мегрінським коридором, який сполучає країну із Нахічеванським анклавом, відірваним від країни. Згідно з угодою, Азербайджан зберіг територіальні переваги, отримані в процесі шести тижнів важких боїв із противником. Під контроль Баку відійшли південні території Нагорного Карабаху, включаючи друге місце анклаву Шушу. Вірменії залишилися лише кілька гірських районів. За невелику частину Нагірного Карабаху, що залишився вірменським, Єревану довелося піти на серйозні поступки - Азербайджану довелося передати контроль над Кельбаджарським, Лачинським та Агдамським районами, які раніше були окуповані, контроль над дорогами Варденіс-Мардакерт і Лачин-Шуша. Великий репутаційний удар був нанесений по іміджу Російської Федерації, яка фактично кинула напризволяще свого регіонального союзника, партнера по ОДКБ Вірменію.

Пояснення результатів. Аналіз «другої карабаської війни» у вересні-листопаді 2020 р. наочно продемонстрував, що в сучасних умовах лише модернізована, технологічно спроможна армія будь-якої держави у змозі протистояти агресії і захищати ії недоторканість і національні інтереси. За чверть століття, поки конфлікт у Нагірному Карабаху знаходився в замороженій стадії, обидві сторони заявляли про готовність вирішити його силою.

Поразка в «першій карабаської війні» примусила Азербайджан почати системну та послідовну модернізацію власних Збройних сил. Сухопутні війська Азербайджану були організаційно зведені в п’ять армійських корпусів - загалом 23 мотострілкові бригади. Також у центральне підпорядкування 
були переведені окрема артилерійська бригада, бригада РСЗВ та протитанковий полк. У кожному армійському корпусі сформовано по одній ударній бригаді для ведення штурмових дій.

Практично із середини 1990-х рр., після гіркої поразки та втрати величезного масиву власної території, Азербайджан почав планомірну та поступову роботу щодо оснащення своєї армії сучасними зразками озброєння і техніки в основному виробництва РФ, Білорусі, Чехії, Ізраїлю та Туреччини. Це, насамперед, російське важке озброєння сухопутних військ - новітні танки Т-90С, бойові машини БМП-3, БТР-82А, 120-мм самохідна артилерійська гармата 2С31 «Відень» на шасі БМП-3. У 2017 р. на озброєнні азербайджанської армії з'являються 38 чеських 152-мм самохідних гаубиць Dana-M1 CZ, 122-мм РC3B RM-70 Vampir, у 2018 р. - білоруські 301-мм РСЗВ В-200 «Полонез».

Активним постачальником сучасної зброї для Збройних сил Азербайджану стає Туреччина. У 2013 р. Азербайджан закупив у турецької компанії Roketsan далекобійні засоби ураження -21 одиницю 300-мм РСЗВ Т-300 Kasirga, які були встановлені на шасі російських вантажівок високої прохідності КАМА3-63502. Крім того, Туреччина надала азербайджанським військовим 122-мм РСЗВ Т-122 Sakarya та 107-мм РСЗВ Т-107 Boran разом із сучасними системами управління вогнем. Ще однією суперсучасною зброєю турецького виробництва на озброєнні азербайджанської армії стала крилата ракета великої дальності SOM (Stand-off Muhimmat Seyir Fuzesi), яка може бути запущена як із повітря, так і з землі та моря.

Після 2016 р. перше місце серед постачальників зброї для азербайджанської армії займає Ізраїль. Азербайджан закуповував в Ізраїлі високоточні протитанкові ракетні комплекси 3-го покоління Spike-LR (до 500 шт.), легкі бронемашини, самохідні гаубиці та безпілотники Heron i Searcher. Лише протягом останнього десятиріччя азербайджанськими військовими були прийняті на озброєння ізраїльські 160-мм PC3B LAR-160, 306-мм PC3B Lynx Extra, оперативно-тактичний комплекс Lora, 155-мм CAY SOLTAM Atmos та багато інших зразків техніки.

Модернізація системи озброєння азербайджанської армії призвела до того, що в рейтингу військової могутності, який складає один з найавторитетніших дослідницьких центрів світу Global Firepower Index (GFI), Азербайджан посів загальне 63-е місце серед 138 країн світу. Ще дві країни Південного Кавказу - Грузія і Вірменія - знаходяться в цьому рейтингу, який оцінює військову міць країн за інтегрованим показником залежно від розмірів військового бюджету, чисельності армії, кількості танків, літаків, підводних човнів та ін., на 93-му та 112-му місці відповідно. За повітряною могутністю Азербайджан зайняв 58-е місце, за кількістю танків - 30-е місце, бронеавтомобілів - 48-е місце, САУ 23-е місце, буксируваної артилерії - 39-е місце [5].

Напередодні спалаху бойових дій Азербайджан помітно випереджав Вірменію за всіма кількісними та якісними показниками військової могутності, про що яскраво свідчить порівняльна характеристика сучасного бойового потенціалу Азербайджану та Вірменії (див. табл. 1).

Таблиця 1

Порівняльна характеристика сучасного бойового потенціалу Азербайджану та Вірменії [6, с. 39; 7]

\begin{tabular}{|l|c|c|c|}
\hline \multicolumn{1}{|c|}{ Показники } & Азербайджан & Вірменія & Співвідношення \\
\hline Кількість населення, млн осіб & 10 & 3 & $3,3: 1$ \\
\hline Кількість військовослужбовців, тис. осіб & 131 & 45 & $2,9: 1$ \\
\hline Мобілізаційний резерв, тис. осіб & 850 & 200 & $4,25: 1$ \\
\hline Танки & 765 & 320 & $2,4: 1$ \\
\hline Бойові машини піхоти, од. & 2600 & 750 & $3,5: 1$ \\
\hline Самохідні арт. установки, од. & 389 & 38 & $10,2: 1$ \\
\hline РСЗВ, од. & 450 & 70 & $6,4: 1$ \\
\hline Оборонний бюджет, млрд дол. США & 2,805 & 1,385 & $2: 1$ \\
\hline
\end{tabular}

Але справжньою «родзинкою другої карабаської війни» стало застосування Азербайджаном турецьких оперативно-тактичних середньовисотних безпілотників із великою тривалістю польоту «Bayraktar TB2». Свою ефективність цей безпілотник показав під час операції «Весняний щит» - розгрому сірійських урядових військ у провінції Ідліб наприкінці лютого - на початку березня 2020 р., під час якої він застосовувався для ведення розвідки, нанесення високоточних ракетних ударів по військах противника, знищення бронетехніки, інженерних та фортифікаційних споруд.

Однак безпілотний арсенал азербайджанської армії не обмежується одним Bayraktar TB2. У 2019 році на її озброєнні стояли два ізраїльських розвідувальних апарати Heron TP i Hermes 4507 (десять одиниць), а також 100 штук дронів-камікадзе SkyStriker i 50 штук дронів-камікадзе Nagor. Саме дрони-камікадзе, 
або барижувальні боєприпаси, останніми роками стають дедалі популярнішими. По суті, це летючі бомби, які здатні десятки хвилин перебувати в повітрі, а потім за наказом оператора атакувати ціль. Азербайджан інвестує також у виробництво власних дронів. Спільний азербайджано-ізраїльський консорціум Azad systems уже представив розвідувальний дрон Aerostar i дронів-самогубців Orbiter1K i Orbiter-3.

Саме за допомогою насамперед безпілотної авіації Азербайджан реалізував безспірне локальне панування в повітрі під час бойових дій. Підрозділи БПЛА Збройних сил Азербайджану опанували в «другій карабаській війні» тактику зграї, коли дрони різного призначення виконують в одному районі різні завдання комплексно: перші викривають цілі, другі здійснюють їх підсвітку, треті - ураження. За допомогою майже півтисячі БПЛА і баражувальних боєприпасів азербайджанці забезпечили ізоляцію поля бою, роздовбуючи колони постачання і ротації вірмен. Завдяки використанню ударних безпілотників Bayraktar TB2, Orbiter-1K і безпілотників-камікадзе типа Harop із потужною 23-кілограмовою боєголовкою, а також SkyStriker Азербайджан зміг нав'язати свій сценарій розвитку конфлікту. При цьому необхідно враховувати вражаючу підтримку Туреччини, яка відповідала за патрулювання неба над Карабахом за допомогою розвідувальних літаків і «літаючих радарів» Boeing 737 AEW \& C. Крім того, в Азербайджану був доступ до турецьких розвідувальних супутників та трьох власних космічних апаратів Azerspace.

«Друга карабаська війна» продемонструвала значне підвищення ролі інформаційного забезпечення проведення як окремих бойових операцій, так і всіх етапів війни. Як зазначив командувач Сухопутних військ Збройних сил України генерал-полковник О. Сирський, «активне інформаційне супроводження дій військ у позитивному контексті створювало перевагу, стимулювало і своє населення, i свої війська. 3 іншого боку, активні заходи з дезінформування негативно впливали на дії противної сторони, сприяли дезорієнтації військ, формуванню панічних настроїв серед військових та цивільного населення, що, насамкінець, і сприяло кінцевому для сторін цього конфлікту результату» [8].

Аналіз азербайджанських YouTube-каналів показав, що ця мережа була створена протягом 2017-2018 років, тому, припускають експерти, азербайджано-турецький альянс почав готуватись і створювати інформаційний фон для звільнення окупованих територій Азербайджану за 2-3 роки до початку активної фази конфлікту. У передконфліктний період інформаційний вплив Азербайджану був сфокусований: на дискредитації всього, що пов'язано з Вірменією, - історії, релігії, культури, демонстрації окупаційної політики Вірменії та апелюванні до легітимності своїх дій на підставі резолюції ООН про територіальну цілісність Азербайджану, поширенні матеріалів патріотичного спрямування; дискредитації вірменської держави та армії. А за два тижні до початку активної фази операції через соцмережі урядовими та неурядовими силами були поширені заклики до громадян не висвітлювати переміщення техніки та військ.

Фактично, $з$ початком бойових дій по всієї лінії фронту почалася і потужна пропагандистська війна між Азербайджаном і Вірменією. 27 вересня 2020 р. Міністерство транспорту, зв'язку та високих технологій Азербайджану попередило про обмеження Інтернету в країні, «щоб запобігти широкомасштабним провокаціям із боку Вірменії». Були заблоковані соцмережі Facebook, Twitter, Instagram, Linkedin, TikTok, месенджери WhatsApp, Facebook Messenger, Skype i Zoom, відеохостинг YouTube. Соцмережі в Азербайджані залишилися доступними через VPN, але такими серверами в країні користується небагато людей.

28 вересня Азербайджан провів інформування для військових аташе іноземних держав із метою підтримки легітимності дій азербайджанської армії та поширив інформацію про виступ глави Азербайджану на Генеральній Асамблеї ООН, що відбувся за два дні до початку конфлікту і був присвячений агресії Вірменії. Запрошені провідні світові ЗМІ, продумана логістика, забезпечення знімальних груп, акредитація, дозволи, маршрути руху, супровід знімальних груп. При цьому з першого дня війни Азербайджан жорстко обмежив поширення неофіційної інформації з районів бойових дій. Влада ретельно контролювала інформаційний потік із цього регіону. Прикладом такого контролю стало порушення Генеральної прокуратурою Азербайджану кримінальної справи проти російського журналіста С. Пєгова, який у своєму телеграм-каналі WarGonzo вів репортажі з Карабаху, відкрито підтримував невизнану НКР.

Оперативно та професійно з перших днів бойових дій виступили засоби масової інформації Азербайджану. На державних телевізійних каналах Az TV, Idman TV, Medeniyyet TV, приватних телеканалах Ictimai Television, ANS TV, Space TV, Lider TV, Azad Azerbaijan TV, Xazar TV, Region TV та ін., друкованих засобах масової інформації, насамперед щоденних газетах «Ени мусават», «Азадлиг», «Азербайджан», «Халг газети» та ін., на новинних Інтернет-порталах, таких як АПА, Новини Азербайджан, 
агентство «Тренд», www.1news.az та ін., одночасно масово та скоординовано стали з’являтися повідомлення щодо перемог азербайджанської армії на кожній ділянці фронту. На всіх без винятку каналах і частотах, у друкованих виданнях практично хвилеподібно почалася трансляція виступів із посланнями, заявами, повідомленнями вищих посадових осіб держави, що демонстрували силу і могутність власних збройних сих. При цьому, як правило, азербайджанські медіа використовували стратегію «одного голосу», коли оприлюднення офіційної інформації походило з одного джерела. Головним ньюсмейкером виступав Президент Азербайджану Г. Алієв. Було повністю запроваджено турецьку модель роботи прес-служби. Спілкування з військовими здійснювалось виключно через прес-офіцерів, офіційні відео надавало лише Міністерство оборони Азербайджану.

Азербайджанські 3МІ починають активно використовувати антивірменські новинні фейки, інформаційні тренди, радикальні заяви і приховані натяки. Такі повідомлення, які кожен може почути, побачити або прочитати, здатні згуртувати населення країни, дати змогу кожному відчути свою належність до певної нації або стану в країні і, навпаки, посіяти сумнів та налаштувати населення ворожої країни проти чинної влади з метою створення в ній напруженої ситуації. Аналітики виокремили кілька тенденцій у використанні каналів доставки інформації. Зокрема, йдеться про посилення діï Telegram-каналів внаслідок відсутності цензури, складності у блокуванні, анонімності та оперативності; поширення застосування платформи Тік Ток i одночасно зниження ролі Facebook, який використовує жорстку політику цензури. Як приклад дезінформаційної атаки, можна навести повідомлення азербайджанського видання Haqqin.az. 27 жовтня 2020 р. про вбивство так званого «міністра оборони і командувача армією оборони Арцаха» генерал-майора Д. Арутюняна. При цьому паралельно в соцмережах був поширений відеоролик його «знищення» за допомогою ударного безпілотника. Надалі ця інформація була спростована вірменською стороною, що достатньо ефективно психологічно вплинуло на обидві сторони конфлікту.

Відображення війни засобами масової інформації стало головним предметом уваги військово-політичного керівництва Азербайджану. Кожна заява про успіхи на фронті, звільнення окупованих населених пунктів обов'язково супроводжувалася відповідними відео- і фотоматеріалами. Інформаційно-психологічні операції стали стрижнем бойових дій азербайджанської армії. За допомогою нового фактора бойових дій - активного використання БПЛА, ударних дронів - Міністерство оборони Азербайджану щодня видавало записи відео та фотографії атак вірменських позицій. Як відомо, на напрямах головних ударів панування в повітрі захопили азербайджанські безпілотники, які цілеспрямовано вибивали бойову техніку і машини постачання противника. Складовою частиною інформаційно-психологічних операцій стала щоденна публікація з боку прес-центру МО Азербайджану в Twitter i Telegram відеороликів за участю бойових дронів, які нібито демонстрували ракетні атаки та удари безпілотників-камікадзе по вірменських силах. Для порівняння - за весь час війни Вірменією не показано жодного відео, де вогневий вплив здійснюється влучно по цілі.

Використовуючи ізраїльську тактику знищення командного складу противника, Азербайджан практично щоденно повідомляв про втрати генералів і офіцерів вірменської армії. Через прес-секретаря Міністерства оборони Азербайджану А. Ейвазова на YouTube-каналі міністерства, на сторінках у Facebook, у телеграм-каналі Karabakh is Azerbaijan та ін. була поширена інформація про поранення в бою під Шушою колишнього міністра оборони Вірменії генерал-полковника С. Оганяна, загибель у боях заступника міністра оборони НКР полковника А. Саркісяна, героя Арцаха полковника С. Шакаряна, командира частини вірменського спецназу полковника В. Асатряна, начальника зв'язку 18 мотострілецької дивізії майора А. Казаряна, командира 77-го окремого бронетанкового батальйону Н. Акобджаняна та багатьох інших.

Війна в Карабасі показала новий формат участі у бойових діях сил спеціального призначення, гірських підрозділів, розвідувальних рот загальновійськових бригад, штурмових груп. Як правило, вони використовувались як штурмові групи для прориву лінії фронту на невеликій ділянці, просочування (інфільтраціi), обходу вузлів оборони. На думку експертів, провідну роль в активній фазі війни в Нагірному Карабасі зіграли саме Сили спеціальних операцій ЗС Азербайджану, які проводили диверсії, руйнували комунікації, завдавали точкові удари та корегували вогонь.

Судячи $з$ того, що президент Азербайджану I. Алієв особисто вітав командувача сил спецоперацій генерала Х. Мірзоєва зі взяттям Гадрута і Шуші, саме результативні тактичні дії штурмових загонів забезпечили успіх цієї операції [9]. Перемога в боях за Гадрут була забезпечена неочікуваним маневром у горах азербайджанських спецпризначенців, які без підтримки бронетехніки самостійно просочилися в проміжках бойових порядків вірмен і захопили це селище, яке мало важливе стратегічне значення. Долю Шуші вирішило захоплення села Карін Так. Геолокація боїв навколо Шуші й відео 3 міста 
свідчило про те, що вуличних боїв там практично не було. На початку листопада азербайджанська гірська піхота та спецпризначенці чисельністю до 200 військовослужбовців через перевали, не маючи важкої техніки, а через негоду й підтримки безпілотників, піднялись на плато в найважчому і безпечному, а тому неочікуваному місці, дістались міста Шуші з північного заходу і лютою нічною атакою вибили ворога 3 верхньої частини міста, більше двох днів відбивали наступ вірмен в очікуванні підкріплення. При цьому гарно спрацювала зв'язка - професійні спецпризначенці з підтримкою 3 дронів.

Одним із головних чинників перемоги Азербайджану у військовому конфлікті з Вірменією на території Нагірного Карабаху було не тільки технічне оснащення армії, а й нова система організації та прийняття рішень у війську, абсолютна інша система розвідки і мережевої центричної війни та система горизонтальних прийнять рішень, коли кожен командир мав право приймати рішення на ураження противника без узгодження з вищестоящими штабами. Комплексне застосування різнорідних сил і засобів, швидкість дій, точне визначення правильної тактики, ефективне забезпечення розвідувальною інформацією в реальному часі - все це було несподівано для противника і характерно практично для кожної локальної операції.

У тактичному плані, враховуючи те, що лінія фронту не змінювалася останні 26 років, а тому залишалася вкрай укріпленої, азербайджанські генерали зробили ставку на різке посилення реактивної артилерії, особливо великого калібру. 300-мм РСЗВ, ізраїльські оперативно-тактичні ракетні комплекси LORA (саме цією ракетною системою був зруйнований стратегічно важливий міст через річку Акарі на трасі між столицею Нагірного Карабаху і вірменським містом Горіс), китайські машини з модульними одноразовими «пакетами», які дозволяли змінювати тип боєприпасів прямо «в полі»-всі ці технології давали можливість ураження на всю глибину бойових порядків, виливалися в удари за сотню кілометрів від фронту по резервах, скупченнях військ, станціях мобільного зв'язку, тилових базах та ін.

За оцінками спеціалістів, середній темп наступу азербайджанської армії становив 1,6 км за добу. Під час бою азербайджанська піхота демонструвала відмінну бойову злагодженість. Пересування один стріляє, інший рухається; взаємне вогневе прикриття бойових пар одна одною; вогневе прикриття пораненого до подальшої евакуації. Головна мета - швидке просування до об'єкта; середній час захоплення та зачистки об'єкта типа «блокпост» - 5-6 хвилин. Середнє напруження використання БПЛА Bayraktar TB2 - 2 вильоти на добу. Стратегічна раптовість дій була досягнута відмовою від оперативного розгортання військ та проведення прихованої мобілізації, коли вона відбувалась шляхом розсилки SMS-повідомлень вибраним військовослужбовцям. Мобілізаційне розгортання відбувалось у три етапи: для реагування на збройний інцидент у Нахічевані, для участі в спільних турецько-азербайджанських навчаннях та безпосередньо перед початком бойових дій.

«Друга карабаська війна» показала високу вразливість бронетехніки радянсько-російського виробництва, зокрема танків, в умовах сучасного бою. Ефективність азербайджанських безпілотників перевищила результативність вірменських наземних протитанкових засобів у кілька разів. Крім того, азербайджанці активно використовували ізраїльський багатофункціональний протитанковий комплекс Spike-LR/ER із ракетами третього покоління (коли операторам не потрібно маркувати ціль після пуску ракети за принципом «вистрілив і забув», тобто розрахунок після пострілу може залишити свою позицію, куди $\epsilon$ ймовірність «прильоту» відповіді), які здатні змінювати цілі в польоті. За підрахунками західних аналітиків, без урахування захоплення азербайджанськими військовослужбовцями бронетехніки як трофеїв, Вірменія під час боїв втратила більше 120 танків різних модифікацій (Азербайджан - 30), 24 броньованих машин, біля 20 бойових машин піхоти, 120 одиниць причепної та 17 самохідної артилерії.

Такі вражаючі втрати свідчать про низьку ефективність або фактичну відсутність комплексної ешелонованої системи ППО вірменської сторони. Практично уперше у світі глибока операція Збройних сил Азербайджану з придушення системи протиповітряної оборони вірмен була проведена виключно безпілотними апаратами. Вірменська армія фактично була позбавлена швидкого виявлення засобами ППО азербайджанських БПЛА і вжиття адекватних засобів щодо відбиття їхніх атак. Крім того, бойові дії в Нагірному Карабасі продемонстрували значне зростання ролі засобів радіоелектронної боротьби, протирадіолокаційних ракет, сучасних засобів постановки перешкод.

Висновки. Успіх Азербайджану забезпечив чіткий курс керівництва держави на повернення захоплених територій та слушно вибраний момент для початку дій. Азербайджан більше 20 років готував своє суспільство до однієї єдиної війни. Довгі роки підготовки, до 20 млрд доларів на сучасне озброєння, союз із регіональним лідером Туреччиною і півтора місяця власне загальновійськової операції 3 тисячами убитих і поранених. Все це на тлі втрати $3 \%$ ВВП у минулому році через війну, падіння ціни на вуглеводні та Ковід. Саме такою була ціна війни за Карабах для Азербайджану. 
Запеклі бої в Нагірному Карабасі з 27 вересня по 10 листопада 2020 року стали одним із наймасштабніших військових зіткнень на пострадянському просторі за кількістю понесених сторонами втрат (близько 10 тис. вбитих, включаючи цивільних осіб, за 44 дні боїв) і за інтенсивністю втрат - середньодобовою кількістю вбитих і за кількістю задіяних сил: до 200 тис. багнетів у сукупності під кінець конфлікту. На днях Азербайджан уперше оприлюднив дані про свої втрати у війні в Карабасі: 2783 загиблих, більше 100 зниклих безвісти, 1245 поранених. Вірменія, за даними свого МОЗ, повідомила про загибель понад 3,3 тисяч військовослужбовців під час загострення карабахського конфлікту. Утім кількість втрат обох сторін може бути ще більшою. В обох країнах триває процес упізнання тіл [10].

Незважаючи на запеклість боїв, азербайджанська армія уникала залучення великих мас піхоти під час бойових операцій. Як правило, бойові дії були пов'язані з невеликими територіальними просуваннями з боку азербайджанської армії і масованим застосуванням нових засобів ведення збройної боротьби - перш за все БПЛА, реактивної і ствольної артилерії нових зразків, засобів РЕБ. Азербайджан застосовував ефективну тактику самостійних дій невеликих груп піхоти, штурмових загонів, просування механізованих підрозділів вглиб оборони противника на велику глибину. Це дало змогу Збройним силам Азербайджану вирішити головне завдання - прорив вірменської оборони і сковування противника на широкому фронті.

3 очевидної технічної переваги азербайджанської армії випливала тактика завдання максимальної шкоди вірменським збройним силам у техніці і матеріальному забезпеченні. У Карабасі ми спостерігали війну нового типу, в якій велику роль відігравали роботизована, дистанційно керована техніка i високоточна зброя. Використання Азербайджаном інструментарію сучасної безконтактної війни у вигляді БПЛА, дронів-камікадзе, РСЗА та ін. призводило до втрати вірменською армією великої кількості бойової техніки та людей.

Одним із головних чинників перемоги Азербайджану у військовому конфлікті з Вірменією на території Нагірного Карабаху було не тільки технічне оснащення армії, а й нова система організації та прийняття рішень у війську, абсолютна інша система розвідки і мережевої центричної війни та система горизонтальних прийнять рішень. На відміну від вірменської армії, яка продовжувала знаходитися в полоні віджилих стереотипів радянських часів, Азербайджан продемонстрував повну перевагу в управлінні та плануванні бойових дій, прогнозуванні їхніх наслідків, мотивації особового складу.

«Друга карабаська війна» продемонструвала нові підходи до застосування гнучких засобів швидкого реагування - сил спеціального призначення, гірських підрозділів, розвідувальних рот загальновійськових бригад, штурмових груп, які завдяки більшої свободи дій надавали нові оперативні можливості під час бойових операцій.

Інформаційне домінування Азербайджану, комплексне використання потужного арсеналу сил та засобів масової інформації - телебачення, радіо, друкованої пропаганди, комп'ютерної мережі, дипломатичних каналів, військових структур психологічних операцій та інформаційної війни - по суті, позбавило Вірменію змоги ефективно протистояти інформаційно-психологічному тиску з боку Баку, чинити ефективний інформаційно-психологічний вплив на населення та особовий склад Збройних сил Азербайджану. Вірменія програла в перший тиждень боротьбу за світовий інформаційний простір, світ орієнтувався на інформацію, яку надавали азербайджанські ЗМІ. Азербайджан панував в інформаційному просторі та демонстрував системність та ієрархічність в інформаційній роботі.

Загалом успіх азербайджанської армії у «другій карабаській війні» став можливим завдяки вмінню військово-політичного керівництва держави враховувати нові тенденції розвитку передових армій світу і робити з них практичні висновки, вмілому та своєчасному запровадженню модернізаційних процесів у власних Збройних силах, їх переоснащенню новітніми зразками озброєння, переходу на сучасну систему організації та прийняття рішень. Ми маємо азербайджанський урок, згідно з яким до повернення своїх земель потрібно довго та системно готуватися, і тоді можна блискавично перемогти в ситуації, коли ця перемога здається неможливою. Перед нашими очима реальний живий приклад того, як треба боротися за свою територіальну цілісність, іти до кінця, як треба вірити, прагнути і навчитися перемагати, щодня думаючи про кожен метр окупованої землі, щодня до сьомого поту працюючи, щоб наблизити час возз'єднання і торжество справедливості.

\section{Література:}

1. Здравомыслов А.Г. Межнациональные конфликты в постсоветском пространстве. Москва : Аспект Пресс, 1999. 378 с.; Золян С. Нагорный Карабах: проблема и конфликт. Москва : Лингва, 2001. 198 с.; Корнелл С. Конфликт в Нагорном Карабахе: динамика и перспективы решения. URL: http://www.sakharov-center.ru/azrus/az_016.htm; Марибашир Е. Стратегия привлечения международных организаций к справедливому разрешению армяно-азербайджанского, нагорно-карабахского конфликта. Гілея. 2017. № 10. С. 425-429; Рустамова П. Нагірний Карабах - спроби 
встановлення справедливості. Зовнішні справи. 2016. № 5. С. 15-17; Рустамова П. Нагірний Карабах: Ходжалинський геноцид: вірмено-азербайджанський конфлікт щодо території Нагірного Карабаху. Зовнішні справи. 2017. № 4. С. 12-15.

2. Алексійченко О.В. Політика Російської Федерації щодо «заморожених» конфліктів на пострадянському просторі. Політологічний вісник. 2013. Вип. 71. С. 503-514. URL: http://nbuv.gov.ua/UJRN/Pv 2013 71 47; Зельманович I.I. Політичні механізми врегулювання заморожених конфліктів сучасності : дис. ... канд. політ. наук : 23.00 .02$. Івано-Франківськ, Львів. 2019. 187 с.; Корж Г. Історія ненависті. Чи був Карабаський конфлікт невідтворотним? Всесвіт. 2017. № 3-4. С. 182-187; Райхель Ю. Карабах. Кремль зацікавлений у підвищенні температури заморожених конфліктів уздовж периметра своїх кордонів. День. 20165 квітня. С. 11, Рябека А. Передумови виникнення нагірно-карабаського конфлікту. Актуальні проблеми міжнародних відносин : збірник наукових праць. Київ. 2011. Вип. 95. Ч. 1. С. 72-74, Чирва Ю.І. Нагірно-Карабаський конфлікт: геополітичний вимір. Збірник наукових праџь [Харківського начіонального педагогічного університету імені Г.С. Сковороди]. Серія : «Історія та географія». 2011. Вип. 40. С.90-94. URL: http://nbuv.gov.ua/UJRN/znpkhnpu_ist_2011_40_22.

3. Туреччина де-факто перекинула війська в Азербайджан - журналіст $29.0 \overline{7} .20$. URL: https://glavred.info/ua/world/turechchina-de-fakto-perekinula-viyska-v-azerbaydzhan-zhurnalist-ozvuchiv-riziki-novini-svitu-10190972.html

4. Президент Азербайджана заявил о завершении войны в Нагорном Карабахе - 11.11.2020. URL: https://zik.ua/news/ world/prezydent_azerbaidzhanu_zaiavyv_pro_zavershennia_viiny_v_nahirnomu_karabasi_986777

5. Рейтинг GFP: Азербайджан обладает самой сильной военной мощью на Южном Кавказе - 04.02.2020. URL: https://interfax.az/view/791302

6. Мониторинг показателей качества жизни населения в странах Содружества Независимых Государств $2016-2019$. Межгосударственный статистический комітет СНГ. Москва, 2020. 82 с.

7. Докладне порівняння військової могутності Вірменії та Азербайджану. URL: https://zbroya.info/uk/blog/19649_ dokladne-porivniannia-viiskovoyi-mogutnosti-virmeniyi-ta-azerbaidzhanu/

8. Олександр Сирський: Війна на Кавказі показала, що без автоматизованої системи управління військами важко досягти результату. URL: https://armyinform.com.ua/2020/12/oleksandr-syrskyj-vijna-na-kavkazi-pokazala-shho-bezavtomatyzovanoyi-systemy-upravlinnya-vijskamy-vazhko-dosyagty-rezultatu/

9. Президент Ильхам Алиев поздравил генерал-лейтенанта Хикмета Мирзоева. - 08.11.2020. URL: https:/az.sputniknews.ru/ karabakh/20201108/425413796/Prezident-Ilkham-Aliev-pozdravil-general-leytenanta-Khikmeta-Mirzoeva.html

10. Азербайджан вперше оприлюднив втрати у війні в Карабасі - тисячі людей - 03.12.2020. URL: https://www.bbc.com/ ukrainian/news-55174141 